\title{
NILAI EKONOMI PEMANFAATAN LIMBAH KELAPA SAWIT MENUJU ZERO WASTE PRODUCTION
}

\author{
Muhammad Arief Dirgantoro ${ }^{\left.{ }^{\star}\right)}$ dan Robiatul Adawiyah ${ }^{1)}$ \\ 1) Staf Pengajar pada Fakultas Pertanian UHO, Kendari \\ ${ }^{1 *}$ Corresponding author email : robiatulada1@gmail.com
}

\begin{abstract}
Abstrak
Tulisan ini bertujuan untuk menguraikan nilai ekonomi dengan pemanfaatan limbah kelapa sawit menuju Zero Waste Production. Satu hektar kelapa sawit, setiap tahunnya menghasilkan 25 ton tandan buah segar (TBS) padahal yang menjadi minyak dan inti sawit hanya sekitar 25\%, dengan demikian 19 ton dari TBS akan menjadi limbah. Dengan semakin gencarnya isu lingkungan maka diperlukan pemanfaatan dan pengendalian limbah industri kelapa sawit yang ramah lingkungan agar dapat memberikan nilai tambah dan mengurangi biaya yang pada akhirnya memberikan keuntungan bagi berbagai pihak, baik pihak perkebunan, pabrik, masyarakat dan lingkungan. Konsep 3R (Reuse, Recyle dan Recovery) akan mendorong setiap penghasil limbah untuk menjadikan limbahnya memiliki nilai ekonomis dan menguragi biaya. Pemanfaatan limbah kelapa sawit dapat mengurangi biaya produksi listrik, briket arang, bahan baku pulp, pakan ternak, dan menghemat biaya pupuk.
\end{abstract}

Kata kunci : nilai ekonomi, pemanfaatan, limbah, isu lingkungan, konsep 3R (Reuse, Recyle dan Recovery)

\begin{abstract}
This paper aims to outline the economic value of the use of palm oil waste towards Zero Waste Production. One hectare of oil palm, annually produce 25 tonnes of fresh fruit bunches (FFB), whereas the oil and palm kernel only about $25 \%$, so 19 tonnes of FFB would be a waste. With the developed environmental issues will require the use and control of industrial waste environmentally friendly palm oil in order to provide added value and reduce costs, which in turn provide benefits to various parties, both the plantations, factories, communities and the environment. The concept of 3R (Reuse, Recycle and Recovery) will encourage each waste generator to make the waste has economic value and reduces costs. Utilization of oil palm waste can reduce the production cost of electricity, charcoal, pulp raw materials, animal feed, and saves the cost of fertilizer.
\end{abstract}

Keywords: economic value, utilization, waste, environmental issues, the concept of 3R (Reuse, Recycle and Recovery)

\section{PENDAHULUAN}

\section{Latar Belakang}

Sektor perkebunan telah memberikan sumbangan cukup berarti bagi perkembangan dan stabilitas ekonomi di Indonesia. Pada saat badai krisis melanda Indonesia, agribisnis di bidang perkebunan tetap eksis dan bahkan mengalami pertumbuhan. 
Dalam era perdagangan bebas, komoditas perkebunan merupakan salah satu komoditas unggulan Indonesia yg mampu memberikan devisa negara. Upaya pengembangan komoditas tersebut diperlukan bukan hanya untuk meningkatkan kuantitas produk, melainkan disertai peningkatan kualitas, keamanan, kontinuitas produksi dengan tingkat harga yang kompetitif sehingga mampu bersaing di pasar Internasional.

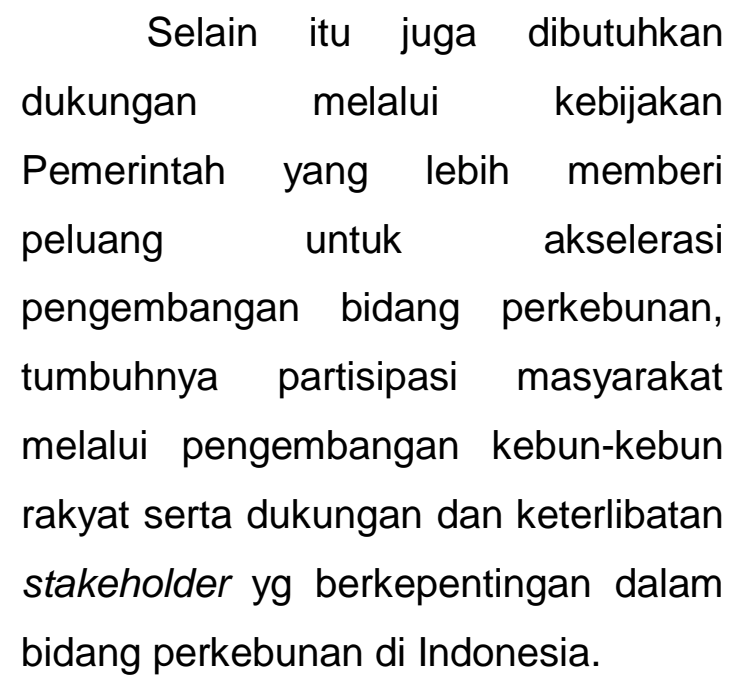

Salah satu komoditas perkebunan yang sangat berpotensi untuk dikembangkan di Indonesia adalah kelapa sawit. Luas areal kelapa sawit di Sulawesi Tenggara sekitar 49.390 dengan produksi sebesar 86.934 ton. Secara nasional pengembangan komoditas ekspor kelapa sawit terus meningkat dari tahun ke tahun, terlihat dari rata-rata laju pertumbuhan luas areal kelapa sawit selama tahun 2004 - 2014 sebesar 7,67\%, sedangkan produksinya meningkat rata-rata $11,09 \%$ tahun $^{-1}$

(http://ditjenbun.pertanian.go.id/berita362-pertumbuhan-areal-kelapasawit meningkat.html).

Peningkatan luas areal kelapa sawit terus terjadi. Pada tahun 20152017 luas areal kelapa sawit berturutturut mencapai 11,$3 ; 11,7$; dan 12,3 juta $\mathrm{Ha}$ dengan produksi 31,1 ; 33,2; dan $35,4^{*}$ ) perkiraan) juta ton CPO (Ditjenbun, 2016). Perkebunan kelapa sawit dikelola oleh perkebunan rakyat (PR), perkebunan besar negara (PBN) dan perkebunan besar swasta (PBS). Produksi kelapa sawit berdasarkan tipe pengelolaannya disajikan pada Gambar 1.

Peningkatan luas areal kelapa sawit diiringi juga dengan pertambahan jumlah pabrik pengolahan kelapa sawit (PKS). Luas areal kelapa sawit tahun 1997 sekitar 2.4 juta Ha dengan jumlah PKS sekitar 160 unit. Pada tahun 2003 luas areal kelapa sawit sekitar 5.2 juta Ha dengan jumlah PKS sebanyak 250 unit (Ditjenbun, 2004). Secara nasional pada tahun 2012 jumlah PKS sebanyak 700 unit dengan total kapasitas 34.284 ton TBS jam ${ }^{-1}$.

Pengembangan agribisnis perkebunan kelapa sawit terkait erat dengan perubahan-perubahan pada lingkungan strategis baik nasional, 
regional, maupun global. Perubahan di tingkat global telah menimbulkan bertambahnya tuntutan konsumen yang cenderung mengacu kepada standar mutu yang dibuat oleh International Standard Organisation (ISO), seperti ISO 9000 untuk sistem manajemen mutu, dan ISO 14000 yang mengikat satu proses produksi yang disyaratkan harus ramah lingkungan.

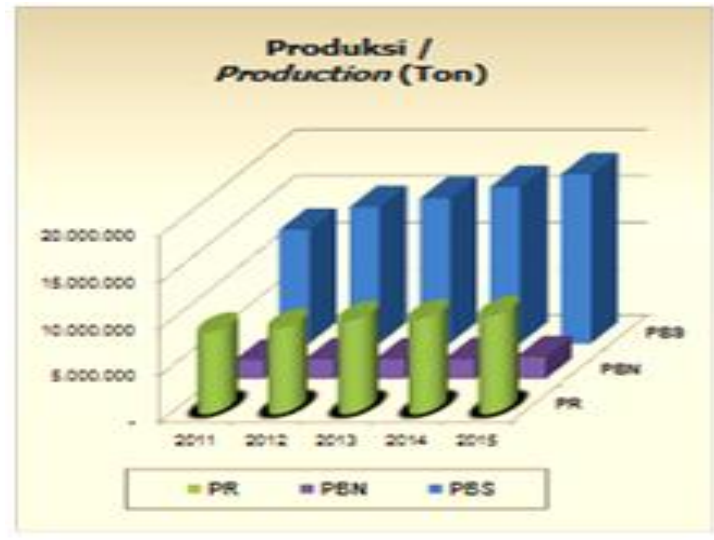

Gambar 1. Produksi kelapa sawit berdasarkan tipe pengelolaannya

Pemahaman bahwa limbah yang dihasilkan dari suatu proses produksi mempunyai nilai ekonomis merupakan suatu paradigma baru yang sedang dikembangkan. Limbah bukan menjadi suatu hal yang harus dihindari atau ditutup-tutupi pengelolaannya tapi bisa mempunyai nilai ekonomis. Konsep 3R (Reuse, Recyle dan Recovery) akan mendorong setiap penghasil limbah untuk menjadikan limbahnya memiliki nilai ekonomis (Agustina, 2006).

\section{Tujuan dan Manfaat}

Tulisan ini bertujuan untuk menguraikan nilai ekonomi pemanfaatan limbah kelapa sawit menuju Zero Waste Production. Pemanfaatan limbah kelapa sawit yang diuraikan dalam tulisan ini adalah produksi listrik, briket arang, bahan baku kertas (pulp), pakan ternak, dan pupuk. Dengan demikian dapat mengurangi biaya produksi dan pengelolaan kelapa sawit juga dapat meningkatkan pendapatan.

\section{LIMBAH KELAPA SAWIT}

Perkebunan kelapa sawit baik yang memiliki pabrik pengolahan minyak maupun tidak, memiliki potensi yang besar dalam mencemari lingkungan. Dalam satu hektar kelapa sawit, setiap tahunnya menghasilkan 25 ton tandan buah segar (TBS) padahal yang menjadi minyak dan inti sawit hanya sekitar 25\%, dengan demikian 19 ton dari TBS akan menjadi limbah. Limbah padat kelapa sawit dapat berupa tandan kosong, cangkang dan sabut, dimana pada 1 ton kelapa sawit menghasilkan limbah berupa tandan kosong kelapa sawit sebanyak $23 \%$ atau $230 \mathrm{~kg}$, limbah cangkang sebanyak $6,5 \%$ atau $65 \mathrm{~kg}$, sabut $13 \%$ atau $130 \mathrm{~kg}$. Buah kelapa sawit yang siap panen dapat dilihat pada Gambar 2. 


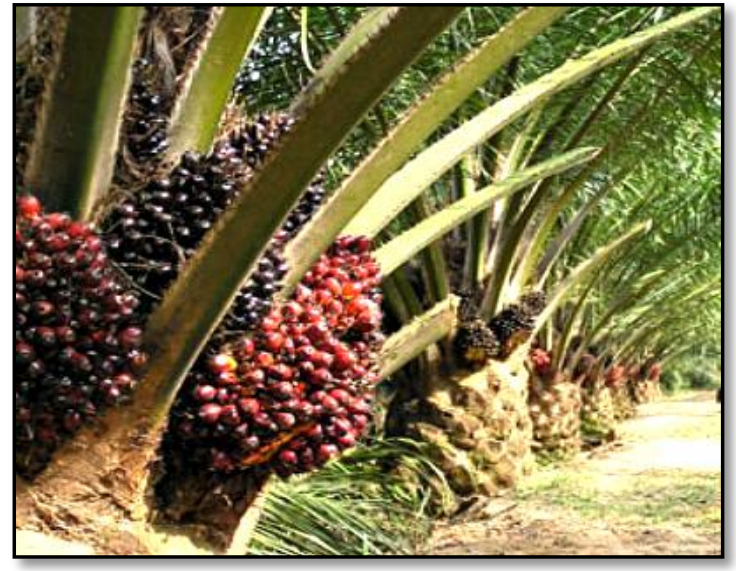

Gambar 2. Buah kelapa sawit yang siap panen

Secara umum, buah kelapa sawit terdiri dari kulit paling luar, serabut, tempurung, dan kernel (inti sawit). Dengan mengacu pada luas areal kelapa sawit pada tahun 2017 sekitar 12.3 juta Ha dengan produksi sekitar 307,5 juta ton TBS, akan dihasilkan sekitar 233,7 juta ton limbah. Limbah tersebut memiliki jumlah dan kesinambungan pasokan yang kontiniu dan tempatnya tidak terpencar, sehingga berpeluang untuk dimanfaatkan. Oleh karena itu penting untuk mengenal potensi limbah kelapa sawit yang dapat memberikan nilai tambah pada industri sawit

(https://kumparan.com/noviyantinurmala1519197736585/dari-limbahmenjadi-berkah-mengenal-potensilimbah-kelapa-sawit-indonesia).

\section{Jenis-jenis Limbah Kelapa Sawit}

Proses pengolahan Tandan Buah Segar (TBS) pada industri kelapa sawit dalam memproduksi minyak sawit mentah/Crude Palm Oil (CPO) dan minyak inti sawit/Palm Cernel Oil (PKO) menghasilkan tiga macam limbah yakni limbah padat, cair, dan gas. Limbah padat merupakan yang paling banyak yakni sekitar 35-40\% dari total TBS yang diolah dalam bentuk tandan buah kosong, serat, cangkang buah, dan abu bakar. Limbah cair dihasilkan dari sisa proses pembuatan minyak kelapa sawit berbentuk cair yang disebut Palm Oil Mills Effluent (POME). Sedangkan limbah gas berasal dari gas buangan pabrik kelapa sawit pada proses produksi CPO

(https://kumparan.com/noviyantinurmala 1519197736585/dari-limbah menjadi-berkah-mengenal-potensilimbah-kelapa-sawit-indonesia).

Tobing et al. (1990) menyatakan bahwa asal dan jumlah bahan buangan PKS terutama diperoleh dari : (a) Air kondesat rebusan (sterilizer condensate), dengan jumlah bahan buangan sekitar 150-175 kg ton ${ }^{-1}$ TBS; (b) Lumpur (sludge water), karena adanya pengenceran, dengan jumlah bahan buangan sekitar 350-400 kg ton 1 TBS; dan (c) Bak pemisah lumpur (clay bath) atau hydrocyclone separator, dengan bahan buangan sekitar 100-150 kg ton ${ }^{-1}$ TBS. Untuk setiap ton TBS yang diolah akan menghasilkan 0.6-0.7 ton limbah pabrik 
kelapa sawit. Pada umumnya satu PKS mengolah TBS dengan kapasitas 60 ton jam $^{-1}$ dengan jumlah jam kerja 20 jam hari ${ }^{-1}$. Dengan demikian setiap PKS akan menghasilkan limbah sekitar 720-840 ton hari ${ }^{-1}$.

\section{PEMANFAATAN LIMBAH KELAPA SAWIT}

Sektor kelapa sawit memiliki kesempatan untuk berpartisipasi dalam Mekanisme Pembangunan Bersih (Clean Development MechanismCDM) dan memperoleh sumber pendapatan baru. Jumlah biomassa yang besar yang diproduksi perkebunan kelapa sawit menyediakan sumberdaya untuk menggantikan bahan bakar fosil, sehingga menurunkan emisi gas karbondioksida $\left(\mathrm{CO}_{2}\right)$. Emisi gas metana $(\mathrm{CH} 4)$ dari kolam pengolahan limbah cair dapat dicegah dengan menggunakan tangki biogas tertutup untuk mengolah limbah pengolahan minyak kelapa sawit (Palm Oil Mill Effluents-POME). Proses ini akan menghasilkan energi dan juga sertifikat penurunan emisi (Certified Emission Reductions - CER).

Selain keuntungan finansial dari penjualan CER, CDM juga membawa manfaat bagi lingkungan. Untuk kedua contoh di atas, terdapat manfaat lingkungan yaitu penggunaan sumberdaya dengan lebih baik karena limbah bisa digunakan sebagai bahan bakar. Sistem tangki biogas tertutup juga akan meningkatkan kualitas limbah cair yang lebih baik dibandingkan dengan sistem kolam tradisional sehingga meningkatkan kualitas lingkungan ekologi pada sungai. Manfaat yang lebih jauh adalah penggunaan POME dan cangkang kelapa sawit (Empty Fruit Bunches - EFB) akan menghasilkan bahan bakar berkualitas tinggi bisa dijual sebagai bahan bakar ke industri atau stasiun pembangkit listrik. Dalam hal ini, energi bisa menjadi produk baru dari sektor kelapa sawit dan berperan secara signifikan untuk mengurangi ketergantungan pada bahan bakar fosil.

Beberapa penelitian telah berhasil membuktikan potensi energi dari limbah kelapa sawit antara lain: pembangkit listrik, briket arang, bahan baku kertas (pulp), pakan ternak, dan pupuk.

\section{Pembangkit Listrik}

Selama ini limbah pelepah kelapa sawit banyak yang dibiarkan. Kalaupun digunakan, biasanya hanya untuk pupuk dengan cara dibakar. Padahal limbah padat kelapa sawit dapat menghasilkan uap yang dapat dijadikan sumber energi (Hartoyo, Pontianak Post, 2 Agustus 2006). 
Cangkang buah kelapa sawit dapat dimanfaatkan sebagai bahan bakar alternatif (alternative fuel oil) pada boiler dan power generation.

Nilai energi panas (calofiric value) dari TKKS sebagai bahan bakar generator listrik dapat mencapai 18 $796 \mathrm{~kJ} \mathrm{~kg}^{-1}$, maka energi yang dihasilkan dapat dikonversikan menjadi listrik dengan jumlah yang cukup signifikan. Sebagai ilustrasi, sebuah PKS dengan kapasitas 200 ribu ton TBS tahun $^{-1}$ menghasilkan 44 ribu ton TKKS (kadar air 65\%) yang mampu membangkitkan energi ekuivalen dengan 2.3 Mwe (megawatt-electric) pada tingkat efisiensi konversi $25 \%$.

Potensi biogas yang dapat dihasilkan dari pengolahan limbah cair juga sangat tinggi. Dari 600-700 kg limbah cair dapat diproduksi sekitar 20 $\mathrm{m}^{3}$ biogas. Dengan mengacu pada data produksi kelapa sawit tahun 2004, limbah cair yang dihasilkan diperkirakan mencapai 37633 juta ton. Limbah ini bisa menghasilkan biogas mencapai 1075 juta $\mathrm{m}^{3}$. Jika nilai kalor biogas rata-rata berkisar antara 4 700-6 $000 \mathrm{kkal} \mathrm{m}^{-3}$ atau 20-24 $\mathrm{MJ} \mathrm{m}^{-3}$, setara dengan 516 ribu ton gas LPG; 559 juta liter solar; 665.5 juta liter minyak tanah; atau $5052.5 \mathrm{MWh}$ listrik.

Potensi limbah cair sebagai penghasil listrik sudah dikembangkan di Malaysia sejak tahun 2001 melalui program Small Renewable Energi Programme (SREP). Salah satu energi terbarukan yang dikembangkan dalam program ini adalah mengolah limbah cair PKS menjadi biogas. Apabila, pembangkit listrik biogas ini menggantikan bahan bakar diesel tingkat efisiensi lebih tinggi karena biaya produksi biogas ini sebesar Rp 200 per kWh. Sedangkan, pemakaian minyak diesel untuk energi listrik di pabrik menghabiskan biaya Rp 3.000 per kWh. Sekarang ini rata-rata pembelian oleh PLN sekitar Rp 975 per Kwh di Sumatera dan di Kalimantan Rp 1.170 per Kwh.

Berdasarkan survei yang dilakukan oleh Direktorat Jenderal Energi Baru, Terbarukan, dan Konservasi Energi (EBTKE) Kementerian ESDM potensi energi listrik yang dihasilkan dari limbah kelapa sawit mencapai 12.654 mega watt (MW) dengan potensi terbesar terdapat di Sumatra (8.812 MW) dan Kalimantan (3.384 MW). Jumlah limbah cair yang dihasilkan oleh pabrik kelapa sawit berkisar 600 - 700 liter/ton tandan buah segar (TBS). Limbah cair kelapa sawit (POME) ini kemudian dimanfaatkan menjadi tenaga listrik melalui proses anaerob digestion 
dengan teknologi covered lagoon atau continuos stirred tank reactor (CSTR).

Limbah cair sawit memiliki kandungan organik kemudian difermentasi dengan bakteri untuk menghasilkan biogas yang mengandung gas methane. $\mathrm{Di}$ Indonesia, pembangunan pembangkit listrik berbasis POME telah dimulai sejak 10 tahun lalu. Dengan pemanfaatan POME menjadi energi listrik, Indonesia dapat berkontribusi pada keseimbangan lingkungan hidup serta Sustainable Development Goals (SDG) sekaligus meningkatkan rasio elektrifikasi nasional.

\section{Briket Arang}

Pusat Penelitian Kelapa Sawit telah berhasil merancang bangun paket teknologi untuk produksi briket arang, baik TKKS maupun cangkang buah kelapa sawit. Karena sifat bahan berbeda, bahan TKKS memerlukan tungku tipe vertikal, sedang untuk cangkang diperlukan tungku horizontal guna menghasilkan arang bermutu tinggi (Nilai Kalor > $5000 \mathrm{kal} / \mathrm{g}$ ). Proses pembriketan dapat dilakukan dengan mesin pembriket tipe ulir dengan kapasitas 1 ton hari $^{-1}$. Mesin ini menghasilkan briket arang berbentuk silinder dengan diameter 5 $\mathrm{cm}$ dan panjang $10-30 \mathrm{~cm}$ sesuai dengan ukuran briket arang komersial dari serbuk gergaji. Keunggulan produk arang ini antara lain permukaannya halus dan tidak meninggalkan warna hitam bila dipegang. Briket arang dapat dimanfaatkan oleh berbagai industri, antara lain industri minyak, karet, gula, dan farmasi. Adapun hasil perhitungan harga pokok produksi, untuk memproduksi briket dengan kapasitas $150 \mathrm{~kg}$ briket per hari adalah $\mathrm{Rp}$ $830 / \mathrm{Kg}$ dengan harga jual yang dapat ditawarkan kepada konsumen sebesar Rp. 1300/Kg,- (Papilo, 2012). Sedangkan harga briket arang kayu di pasar swalayan dijual dengan harga Rp 12.000/2,5 kg.

\section{Bahan Baku Kertas (Pulp)}

Tandan kosong kelapa sawit (TKKS) dapat diolah menjadi kertas, pengganti kertas berbahan baku kayu yang selama ini dikenal luas di masyarakat. Kebutuhan pulp untuk kertas dan papan serat di Indonesia sampai saat ini sebagian masih dipenuhi dari impor. Mengingat bahan baku kertas dari kayu semakin menipis maka salah satu potensi yang cukup besar untuk menghasilkan pulp dalam negeri adalah dengan memanfaatkan batang dan TKKS.

Teknologi untuk mengolah TKKS menjadi bubur kertas ( $p u l p)$ dan teknologi memproses pulp menjadi 
kertas sudah dikembangkan di Malaysia. Kualitas kertas dari TKKS yang dihasilkan Malaysia jauh lebih bagus dibandingkan dengan kertas lokal yang diproduksi di Indonesia. Malaysia, sebagai penghasil kelapa sawit terbesar di dunia mulai memanfaatan TKKS menjadi kertas pada pertengahan dekade 1990-an.

Di Indonesia, perusahaan Malaysia bekerjasama dengan PT
Perkebunan Nusantara (PTPN) III mengembangkan pulp dari TKKS, dengan mengoperasikan 11 pabrik PKS berkapasitas produksi 510 t TBS $\mathrm{jam}^{-1}$. Berdasarkan perhitungan, dari 510 ton kapasitas terpasang PKS dengan asumsi kapasitas terpasang hanya $80 \%$, maka akan dihasilkan pulp sekitar 151300 t tahun $^{-1}$ (Tabel 1).

Tabel 1. Pabrik Pengolahan Kelapa Sawit PTPN III

\begin{tabular}{lcc}
\hline Nama Pabrik & Kapasitas Produksi (t TBS/jam) & Produksi Pulp (t/tahun) ${ }^{\star}$ ) \\
\hline Rambutan & 30 & 8900 \\
Sei Mangkei & 30 & 8900 \\
Sei Silau & 60 & 17800 \\
Aek Nabara Selatan & 60 & 17800 \\
Sisumut & 30 & 8900 \\
Aek Torop & 60 & 17800 \\
Aek Raso & 30 & 8900 \\
Torgamba & 60 & 17800 \\
Sei Baruhur & 30 & 8900 \\
Sei Daun & 60 & 17800 \\
Sei Meranti & 60 & 17800 \\
Total & $\mathbf{5 1 0}$ & $\mathbf{1 5 1 3 0 0}$ \\
\hline
\end{tabular}

Keterangan: *) Data Diolah

\section{Pakan Ternak}

Bahan pakan ternak dari limbah perkebunan kelapa sawit dapat diproduksi antara lain dari bungkil inti sawit dan pelepah serta daun. Bungkil inti sawit atau Palm Kernel Meal (PKM) adalah ampas dari proses pembuatan minyak sawit mentah. Sementara jenis pakan ternak dari sawit lainnya adalah Palm Kernel Expeller (PKE) yang merupakan limbah inti sawit (palm kernel) yang telah diperas minyaknya untuk menghasilkan palm kernel oil (PKO). Kernel Expeller (PKE) diolah menjadi bubuk dengan harga $\mathrm{Rp}$ 800.000 per ton dan dapat dimanfaatkan sebagai pencampur makanan ternak, khususnya sapi perah.

Pabrik kelapa sawit di Indonesia mulai memproduksi PKE pada tahun 2010 dengan tujuan ekspor pasar Selandia Baru dan saat ini, ekspor PKE telah meluas ke Korea Selatan, China, 
Vietnam, Belanda, dan Thailand. Perkembangan teknologi turut mendorong optimalisasi pemanfaatan limbah sawit untuk pakan ternak. Pada bulan Mei 2017, sebuah perusahaan patungan Belgia, Inggris, dan Denmark mulai membangun pabrik alternatif protein untuk pakan ternak senilai US\$ 500 juta atau sekitar Rp 6,65 triliun di Kawasan Ekonomi Khusus (KEK) Sei Mangkei, Sumatera Utara. Pabrik tersebut akan menjadi animal feed terbesar di dunia dengan melakukan pengolahan bahan baku pakan ternak yang berasal dari serangga yang banyak ditemukan di tandan kosong kelapa sawit.

\section{Pakan Ternak Sapi}

Limbah padat kelapa sawit berpotensi sebagai sumber pakan ternak. Hasil penelitian Utomo (1999) menunjukkan bahwa limbah padat kelapa sawit mengandung: bahan kering $81.56 \%$; protein kasar $12.63 \%$; serat kasar $9.98 \%$; lemak kasar $7.12 \%$; kalsium $0.03 \%$; fosfor $0.003 \%$; dan energi $154.0 \mathrm{kal} 100 \mathrm{~g}^{-1}$. Sedangkan hasil analisis terhadap berbagai jenis rumput yang tumbuh di perkebunan kelapa sawit di Kabupaten Kotawaringin Barat menunjukkan bahwa rumput tersebut mengandung: bahan kering $83.15 \%$, protein kasar $7.27 \%$, karbohidrat $14.32 \%$, lemak kasar $1.84 \%$, kalsium $0.08 \%$, fosfor $0.004 \%$, dan energi $102.02 \mathrm{kal}^{100 \mathrm{~g}^{-1}}$ (http://infopeternakan.blogspot.com/2011/08/ pemanfaatan-limbah-kelapa-sawitdalam.html).

Pemberian limbah padat kelapa sawit dalam bentuk segar secara ad libitum kepada sapi PO jantan memberikan pertambahan bobot badan harian (PBBH) $770 \mathrm{~g} \mathrm{ekor}{ }^{-1}$ hari $^{-1}$, sedangkan rata-rata $\mathrm{PBBH}$ sapi yang diberi pakan rumput alami hanya 250 $g$ ekor $^{-1}$ hari ${ }^{-1}$. Pada domba, pemberian limbah padat $1 \%$ dari bobot badan, baik dalam bentuk segar, complete feed block (CFB) tanpa fermentasi maupun CFB fermentasi masing-masing memberikan PBBH 45, 64, dan $83 \mathrm{~g} \mathrm{ekor}^{-1}$ hari $^{-1}$. Pada uji preferensi terhadap 25 ekor sapi Madura, limbah padat kelapa sawit pada akhirnya sangat disukai, namun perlu waktu adaptasi 4-5 hari.

Pakan sapi dari kebun sawit lebih murah dibandingkan pakan sapi biasa. Mengandalkan bahan yang tersedia di kebun sawit, seperti pelepah daun sawit harganya hanya Rp 800 - Rp 1.200/kg. Dalam sehari, untuk mencukupi kebutuhan pakan sapi yang sekitar $10-15 \mathrm{~kg} / \mathrm{ekor}$ akan menghabiskan biaya sekitar Rp12 ribu/ekor, dengan penggunaan pakan umumnya menghabiskan Rp15 ribu - 
Rp20 ribu/ekor/hari. Dengan pakan ini, average daily gain (ADG)-nya (ratarata pertambahan bobot badan) sekitar $0,8-1 \mathrm{~kg}$.

\section{Pakan Ternak Ayam Broiler}

Pada pemeliharaan ayam broiler, ransum merupakan faktor produksi yang membutuhkan biaya paling tinggi (60-70\%). Harga ransum di Indonesia relatif mahal dibandingkan dengan nilai jual produk unggas. Salah satu penyebab tingginya harga ransum di Indonesia adalah sebagian besar bahan dasar ransum masih diimpor.

Lumpur sawit (LS) merupakan salah satu produk samping pengolahan CPO. Pada proses produksi CPO dihasilkan LS (setara kering) sebanyak $2 \%$ dari minyak sawit, sehingga LS ini akan menimbulkan polusi apabila tidak melalui proses pengolahan limbah. Untuk itu perlu dimanfaatkan sebagai bahan baku ransum. Namun demikian LS mengandung serat kasar yang tinggi serta daya cerna yang rendah sehingga penggunaannya dalam ransum unggas sangat terbatas. Untuk itu perlu dilakukan beberapa upaya pengolahan agar penggunaannya bisa ditingkatkan. Salah satu usaha untuk meningkatkan nilai gizi LS untuk pakan adalah melalui fermentasi (Barker et al., 1981; Pasaribu et al., 1998; Sinurat et al., 1998; Purwadaria et al., 1999; Bintang et al., 2000).

Pada umumnya penyimpanan produk konvensional seperti tepung ikan, jagung, dan bungkil kedelai direkomendasikan tidak lebih dari 3 bulan. Sementara Pasaribu et al. (2001) melaporkan bahwa penyimpanan produk fermentasi LS selama 3 bulan tidak nyata menyebabkan perubahan nilai gizi terutama protein. Sinurat et al., (2001) melakukan penelitian dengan tujuan untuk pengujian ransum yang mengandung LS fermentasi pada beberapa waktu penyimpanan terhadap respon ayam broiler. Hasil analisis menunjukkan bahwa penggunaan LSF yang disimpan sampai 3 bulan pada level sampai dengan $10 \%$ mampu mengimbangi ransum kontrol sehingga tingkat konsumsinya sama dengan ransum kontrol dan menghasilkan $\mathrm{PBH}$ yang sama pula. Dari hasil penelitian ini dapat disimpulkan bahwa LSF yang disimpan sampai dengan 3 bulan dapat diberikan sampai tingkat $10 \%$ dalam ransum ayam broiler.

\section{Pupuk Organik}

Peraturan Pemerintah yang mengatur tentang pemanfaatan limbah cair untuk digunakan sebagai pupuk pada lahan di perkebunan kelapa sawit 
adalah: (1) Keputusan Menteri Negara Lingkungan Hidup Nomor 28 tahun 2003 tentang Pedoman Teknis Pengkajian Pemanfaatan Air Limbah dari Industri Minyak Sawit pada Tanah di Perkebunan Kelapa Sawit dan (2) Keputusan Menteri Negara Lingkungan Hidup Nomor 29 Tahun 2003 tentang Pedoman Syarat dan Tata Cara Perizinan Pemanfaatan Air Limbah Industri Minyak Sawit pada Tanah di Perkebunan Kelapa Sawit.

\section{Kompos dari Tandan Kosong Kelapa Sawit (TKKS)}

Limbah padat kelapa sawit berupa TKKS umumnya dapat dimanfaatkan kembali di lahan perkebunan kelapa sawit untuk dijadikan pupuk kompos. Tandan kosong kelapa sawit mencapai $23 \%$ dari jumlah pemanfaatan limbah kelapa sawit sebagai alternatif pupuk organik juga dapat menghemat penggunaan pupuk sintesis sampai dengan $50 \%$. Total biaya investasi produksi kompos dari TKKS berkisar Rp 4 miliar untuk PKS dengan kapasitas 30 t TBS jam $^{-1}$. Dengan asumsi produksi kompos per hari 60 ton, maka biaya produksi kompos adalah $\mathrm{Rp} 150 \mathrm{~kg}^{-1}$. Dengan harga jual kompos bulk Rp $400 \mathrm{~kg}^{-1}$, keuntungan langsung yang diperoleh sebesar Rp $366 \mathrm{~kg}^{-1}$ atau sekitar 2.28 miliar tahun $^{-1}$.
Hasil penelitian Wahono et al. (2003) menunjukkan bahwa: ditinjau dari parameter kematangan kompos seperti rasio $\mathrm{C} / \mathrm{N}$, profil temperatur, penyusutan volume dan penampilan fisik kompos, kecepatan proses peng-komposan TKKS dengan penambahan aktifator (OrgaDec, Biostar, dan EM4) dan pengkomposan tanpa aktivator relatif sama yaitu sekitar 13 minggu, (2) kebutuhan air untuk proses pengkomposan TKKS berkisar antara 1.7-2.3 $\mathrm{m}^{3}$, dan (3) kandungan unsur hara kompos sekitar $0.4 \%(\mathrm{~N}) ; 0.029-0.05 \%\left(\mathrm{P}_{2} \mathrm{O}_{5}\right) ; 0.15-$ $0.2 \%\left(\mathrm{~K}_{2} \mathrm{O}\right)$.

\section{Aplikasi Limbah Cair Pabrik Kelapa Sawit pada Perkebunan Kelapa Sawit}

Menurut Tobing dan Loebis (1989) limbah cair pabrik pengolahan kelapa sawit mengandung unsur hara yang tinggi seperti $\mathrm{N}, \mathrm{P}, \mathrm{K}, \mathrm{Mg}$, dan $\mathrm{Ca}$, sehingga limbah cair tersebut berpeluang untuk digunakan sebagai sumber hara bagi tanaman kelapa sawit, di samping memberikan kelembaban tanah, juga dapat meningkatkan sifat fisik-kimia tanah, serta dapat meningkatkan status hara tanah. Kandungan hara pada $1 \mathrm{~m}^{3}$ limbah cair setara dengan $1.5 \mathrm{~kg}$ urea; 0.3 kg SP-36; 3.0 kg MOP; dan 1.2 kg kieserit. Pabrik kelapa sawit (PKS) dengan kapasitas $30 \mathrm{t} \mathrm{jam}^{-1}$ akan 
menghasilkan sekitar $480 \mathrm{~m}^{3}$ limbah cair hari ${ }^{-1}$, sehingga areal yang dapat diaplikasi sekitar 100-120 Ha.

Pembangunan instalasi aplikasi limbah cair membutuhkan biaya yang relatif mahal. Namun investasi ini diikuti dengan peningkatan produksi TBS dan penghematan biaya pupuk sehingga penerimaan juga meningkat. Penggunaan limbah cair mampu meningkatkan produksi TBS $16-60 \%$. Aplikasi limbah cair $12.6 \mathrm{~mm} \mathrm{ECH} \mathrm{ha}^{-1}$ bulan $^{-1}$ dapat menghemat biaya pemupukan hingga $46 \%$. Aplikasi limbah cair tersebut akan mengurangi biaya pengolahan limbah.

\section{KESIMPULAN}

Kelapa sawit adalah salah satu komoditas andalan Indonesia yang perkembangannya demikian pesat. Sektor kelapa sawit memiliki kesempatan untuk berpartisipasi dalam Mekanisme Pembangunan Bersih (Clean Development Mechanism-CDM) dan memperoleh sumber pendapatan baru. Jumlah biomassa yang besar yang diproduksi perkebunan kelapa sawit menyediakan sumberdaya untuk menggantikan bahan bakar fosil, sehingga menurunkan emisi gas karbondioksida $\left(\mathrm{CO}_{2}\right)$. Emisi gas metana $(\mathrm{CH} 4)$ dari kolam pengolahan limbah cair dapat dicegah dengan menggunakan tangki biogas tertutup untuk mengolah limbah pengolahan minyak kelapa sawit (Palm Oil Mill Effluents - POME). Proses ini akan menghasilkan energi dan juga sertifikat penurunan emisi (Certified Emission Reductions - CER).

Limbah yang dihasilkan dari proses pengolahan minyak kelapa sawit berupa limbah cair dan padat. Dengan keseragaman sifat-sifat dan keberadaan limbah kelapa sawit yang ketersediaannya melimpah, berkelanjutan, dan tidak bersaing dengan kebutuhan manusia maka peluang pengolahan limbahnya sangat prospektif. Pemanfaatan limbah kelapa sawit dapat mengurangi biaya produksi listrik, briket arang, bahan baku kertas (pulp), pakan ternak, dan menghemat biaya pupuk.

\section{DAFTAR PUSTAKA}

Agustina, H. 2006. Land Application sebagai Alternatif $3 R$ pada Industri Kelapa Sawit. Kementerian Negara Lingkungan Hidup. Jakarta.

Aritonang, D. 1986. Perkebunan kelapa sawit sebagai sumber pakan ternak di Indonesia. Jurnal Penelitian dan Pengembangan Pertanian V(4): 93-99.

Barker, T.W., N.J. Droulisco, and J.T. Worgan. 1981. Composition and nutritional evaluation of Asfergillus oryzae biomass grown on palm oil processing effluents. J. Sci. Food Agric. 32: 1014-1020. 
Ditjenbun. 2014. Pengolahan kelapa sawit dan pengelolaan limbah pabrik kelapa sawit. Tim standarisasi pengolahan kelapa sawit. Jakarta. 29 hal.

Papilo, P. 2012. Briket Pelepah Kelapa Sawit Sebagai Sumber Energi Alternatif yang Bernilai Ekonomis dan Ramah Lingkungan. Jurnal Sains, Teknologi dan Industri. Vol 9 no 2: 68-78.

Pasaribu, T., A.P. Sinurat, T. Purwadaria, Supriyati, J. Rosida, dan H. Hamid. 1998. Peningkatan nilai gizi lumpur sawit melalui proses fermentasi. Pengaruh jenis kapang, suhu dan lama proses enzimatis. JITV 3: 237-242.

Pasaribu, T., T. Purwadaria, A.P. Sinurat, J. Rosida, dan D.O.D. Saputra. 2011. Evaluasi nilai gizi lumpur sawit hasil fermentasi dengan Aspergillus niger pada berbagai penyimpanan. JITV 6: 233238.

Sinurat, A.P.,T. Purwadaria, H. Surachman, H. Hamid, dan I.P. Kompiang. 1998. Pengaruh suhu ruangan fermentasi dan kadar air substrat terhadap nilai gizi produk fermentasi lumpur sawit. JITV 3: 225-279. Sinurat, A.P.,T. Purwadaria, P. Ketaren, D. Zainuddin dan I.P. Kompiang. 2000. Pemanfaatan lumpur sawit untuk ransum unggas. (1) Lumpur sawit kering dan produk fermentasinya sebagai bahan pakan ayam broiler. JITV 5: 107-112.

Sinurat, A.P.,T. Purwadaria, T. Pasaribu, J. Darma, I.A.K. Bintang, dan M.H. Togatorop. 2001. Pemanfaatan lumpur sawit untuk ransum unggas. (3) Penggunaan produk fermentasi lumpur sawit sebelum dan setelah dikeringkan dalam ransum ayam pedaging. JITV 6: 107112.

Tobing, P.L. dan B. Lubis. 1990. Pengendalian limbah pabrik kelapa sawit secara biologi. Bulletin Balai Penelitian Perkebunan. Medan 15 (3): 107-111.

Wahyono, S, F. Sahwan, F. Suryanto, dan A. Waluyo. 2003. Pembuatan Kompos dari Tandan Kosong Kelapa Sawit. Prosiding Seminar Teknologi untuk Negeri 2003, Vol I, hal. 375-386. BPPT. Jakarta. 